\title{
CHANGES TO THE BUSINESS BREAKDOWN STRUCTURE OF THE RAILWAY SECTOR IN THE EUROPEAN UNION IN THE PERIOD 1991-2016
}

\author{
JULIUSZ ENGELHARDT \\ University of Szczecin, Faculty of Management and Economics of Services, POLAND \\ e-mail: juliusz.engelhardt@wzieu.pl
}

RECEIVED
ACCEPTED
JEL
CLASSIFICATION

KEYWORDS

ABSTRACT

\author{
18 January 2018 \\ 2 September 2018 \\ L92, H54
}

European Union, railway sector, railway monopolies, institutional regulators, the railway market, managers of railway infrastructure, railway undertakings

The article discusses the main changes concerning business breakdown structure of the European Union railway sector in the period 1991-2016. Until the beginning of the 1990s, railway transport in all member states of today's European Union had been carried out by unified, integrated public-sector companies, whose actual monopolistic position was legally protected. The year 1991 constitutes the demarcation line that fundamentally outlines directions of changes in the management of railway undertakings laid down in Directive 91/440. During the first stage of implementation of the recommended changes, which had been taken place until the end of the 1990s, only such member states as Sweden, Great Britain and Germany undertook extensive reforms of their own railway sectors, while the other countries were rather hesitant to implement proposed changes. The other Member States, which implemented the recommended reforms of their railway sectors, would mainly choose the holding model. The institutional-breakdown structure of the railway sector, which completely differed from the one from 1991, had been implemented by the end of 2016. Moreover, independent, institutional regulators of the railway market had been selected in all member states. Railway infrastructure managers with specific status, operating on the basis of a dedicated-group of railway legislation, took over the management of publicly available railway infrastructure. On the other hand, the rail freight and passenger services were provided by numerous railway undertakings, both those created from the "old" railway monopolies, and those from the private sector. In essence, the European Union railway sector in the years 1991-2016 underwent a transition from a monopoly to a market.

\section{Introduction}

In the history of European rail transport provided on the area of the contemporary European Union, there can be distinguished several stages of development of railway undertakings, namely (Wielopolski, 1975, pp. 230-264):

- the stage of formation and operation of railway undertakings established as joint-stock companies with dominant private equity in the second half of the 19th century, 
- the stage of development of mixed, public-private railway enterprises in the years 1880-1910,

- the stage of nationalization of railways that started in 1879 (the Kingdom of Prussia) and ended in 1948 (the United Kingdom).

It is worth pointing out that European railway undertakings were created on the basis of assets of the newlycreated railway lines, as well as passenger and goods transport services provided on these lines with the use of the purchased rolling stock. With this specific mode of operation, they constituted - in the modern sense - integrated enterprises, which, as part of further evolution, expanded the scope of their activities by including various types of ancillary, supporting and social activities.

Due to the transition through the indicated stages of ownership changes, the period of several decades after the Second World War, until the end of the 1990s, was characterized by the domination of private sector in almost the entire European railway sector, as well as establishment of single, monopolistic national railway undertakings with an integrated structure in most countries. This integrated structure included combination of activities carried out by one entity, which concerned construction, maintenance and operation of infrastructure (railway lines); transport activities (freight and passenger transport); and many types of ancillary and supporting activities, such as energy and telecommunications, IT, infrastructure construction and renovation services, maintenance and repair of rolling stock services, social welfare activities for employees, as well as health and housing services.

The conditions for establishment of State railway monopoly in the past in the contemporary European Union countries, varied for countries from Western Europe ${ }^{1}$ and Central and Eastern Europe. ${ }^{2}$ A substantial proportion of the problems that occurred after several decades of functioning of monopolistic railway structures, had a common denominator - namely, constant unprofitability of provided business activities, due to, among others, tight state control of tariffs; lack of motivation to economize activities; an omnipotent political owner (state) making all important decisions, while the decision-making autonomy of management staff was substantially restricted; and use of railway undertakings to achieve socio-economic goals, such as employment of overstaffed personnel in them, and entrusting them with various state administration tasks, such as customs and sanitary, construction administration, pension systems and other services. In the countries of Western Europe, state railway monopolies encountered problems related to a cyclically growing debt, which had to be reduced by the owner every few years. Whereas, railway monopolies in Central and Eastern Europe countries did not run into debts, as the planned economy did not allow for that. Nevertheless, they struggled with constant insufficient transport capacity in regards to planned transport, shortage of all supply and intermediate goods, as well as showed significant technological development delays in relation to Western railways.

Table 1 lists integrated railway undertakings from the first half of the 1990s operating in the today's European Union countries, which monopolized the railway transport activity in those countries at the time.

${ }^{1}$ In Western Europe, one of the arguments presented was that railway network constitutes natural monopoly characterized by many benefits of transport service. Moreover, an important argument for State railway monopoly were social (the state seeking to provide transport services for those areas of the country, where their provision would not be profitable for private enterprises) and political considerations (in some countries, political parties that favoured the nationalization of basic industries and transport were in power).

2 In the sphere of influence of the Soviet Union after the Second World War, a dogma of the socio-economic superiority of state (social) ownership over private property was in force. Thus, State railway monopoly was a desirable and obvious form in this group of countries, primarily for ideological and political reasons. 
Table 1. Integrated railway undertakings that monopolized the railway transport activity in the European Union countries at the time - as of January 1, 1992

\begin{tabular}{|c|c|c|c|}
\hline \multirow[b]{2}{*}{ Country } & \multirow{2}{*}{$\begin{array}{l}\text { The year } \\
\text { of accession to the } \\
\text { European Union }\end{array}$} & \multicolumn{2}{|r|}{ Integrated railway undertaking } \\
\hline & & $\begin{array}{l}\text { international } \\
\text { symbol }\end{array}$ & full name \\
\hline \multicolumn{4}{|r|}{ EU - 15 Group } \\
\hline Belgium & 1958 & SNCB & $\begin{array}{l}\text { Société nationale des chemins de fer belges - The National Railway Company } \\
\text { of Belgium. }\end{array}$ \\
\hline Germany & 1958 & $\mathrm{DB}^{*}$ & Deutsche Bahn AG - The German Railway AG. \\
\hline France & 1958 & SNCF & Société nationale des chemins de fer français - National society of French Railways. \\
\hline Italy & 1958 & FS & Ferrovie dello Stato Italiane - Włoskie Koleje Państwowe The Italian State Railways. \\
\hline Luxembourg & 1958 & CFL & $\begin{array}{l}\text { Société Nationale des Chemins de Fer Luxembourgeois - The Luxembourg National } \\
\text { Railway Company. }\end{array}$ \\
\hline The Netherlands & 1958 & NS & Nederlandse Spoorwegen N.V. - The Dutch Railways. \\
\hline Denmark & 1973 & DSB & Danske Statsbaner - The Danish State Railways. \\
\hline Ireland & 1973 & IE & larnród Éireann - Irish Rail. \\
\hline Great Britain & 1973 & BR NIR & British Rail Northern Ireland Railways. \\
\hline Greece & 1981 & OSE & 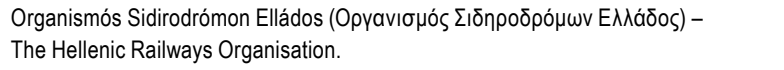 \\
\hline Spain & 1986 & RENFE & $\begin{array}{l}\text { Red Nacional de los Ferrocarriles Españoles - The National Network of Spanish } \\
\text { Railways. }\end{array}$ \\
\hline Portugal & 1986 & $\mathrm{CP}$ & $\begin{array}{l}\text { Comboios de Portugal, Entidade Pública Empresarial - The Portuguese Railways, } \\
\text { a state-owned company. }\end{array}$ \\
\hline Austria & 1995 & ÖBB & Österreichische Bundesbahnen - The Austrian Federal Railways. \\
\hline Finland & 1995 & VR & Valtionrautatiet - Government-owned railway. \\
\hline Sweden & 1995 & $S J^{* *}$ & Statens Järnvägar - Government-owned railway \\
\hline \multicolumn{4}{|r|}{ EU - 13 Group } \\
\hline The Czech Republic & 2004 & $\mathrm{Č}^{* * *}$ & České dráhy - Czech Railways. \\
\hline Estonia & 2004 & EVR & Eesti Raudtee - Estonian Railways. \\
\hline Hungary & 2004 & MAV & Magyar Államvasutak - The Hungarian State Railways. \\
\hline Lithuania & 2004 & LG & Lietuvos geležinkeliai - Lithuanian Railways. \\
\hline Latvia & 2004 & LDZ & Latvijas dzelzcelı̌s - Latvian Railways. \\
\hline Poland & 2004 & PKP & Polskie Koleje Państwowe - The Polish State Railways. \\
\hline Slovenia & 2004 & Sž & Slovenske železnice - Slovenian Railways. \\
\hline Slovakia & 2004 & ŽSR ${ }^{* * *}$ & Železnice Slovenskej Republiky - Railways of the Slovak Republic. \\
\hline Bulgaria & 2007 & BDŻ & Български държавни железници - The Bulgarian State Railways. \\
\hline Romania & 2007 & CFR & Căile Ferate Române - The National Society of Romanian Railways. \\
\hline Croatia & 2013 & $\mathrm{HŽ}$ & Hrvatske željeznice - The Croatian Railways \\
\hline
\end{tabular}

* The German Railway DB was created as a result of the merger of the former German railways Deutsche Reichsbahn and the German Federal Republic Deutsche Bundesbahn in 1994.

** Starting from 1989, the process of successive transfer of railway infrastructure from SJ to the state office Banverket ended in 1996

*** ČD and ŽSR were created in the form of integrated railway companies as a result of the division of former Czechoslovak State Railways ČSD in 1993

Source: own study based on data from the websites of the mentioned railway undertakings or their legal successors.

\section{The new market governance in the European railway sector after 1991}

The new market governance of the railway sector after 1991 was shaped by subsequent adoption of directives, which included recommendations for mandatory implementation of the railway laws by Member States, and the 
regulations of the European Parliament and the Council, which took precedence over the laws of these countries. Furthermore, the European Commission issued its own implementing regulations and decisions, as well as other documents of informative and order nature.

In 1991, the economic policy representatives of the European Economic Community (EEC) of that time, decided to carry out fundamental reforms of the railway sector in the entire group, based on the guidelines presented in Directive $91 / 440$ of July $1991{ }^{3}$ The Directive contained four groups of fundamental recommendations for Member States, which can be identified as pillars of the new market governance in the European railway sector.

The first pillar concerns guaranteeing the independence of the management of railway undertakings, establishment of a management system appropriate for commercial companies, and improvement of the financial structure of railway undertakings. The second pillar separates railway infrastructure management functions from the operation functions (transport operations) in railway undertakings. The third pillar regards implementation of the provision concerning payment for access to railway infrastructure services, whereas the forth provides international groups of railway undertakings and railway undertakings that offer combined transport of goods, with access to the network of the Member States.

Despite the formally announced policy of demonopolization and liberalization of the EU railway sector and the incentives presented by the European Commission, Member States were initially reluctant to implement the recommended reforms. In the first half of the 1990s, only two countries decided on the fundamental reforms of their own railway sector, namely Sweden, which started reforms while remaining outside the EEC, and the United Kingdom. In case of Sweden, the implementation of railway reforms in 1989, that is two years before the adoption of Directive 91/440, resulted in the creation of a government agency called Banverket, which until 1996 had successively taken over railway network management, rail operation, as well as the allocation of infrastructure potential, and charging for access to infrastructure, determined on the basis of marginal costs. ${ }^{4}$

Banverket, as the budgetary unit of the Swedish government, was in no way related to the old "entrenched" state railway company SJ. In 2010, the office responsible for the construction and maintenance of the basic transport infrastructure in Sweden, under the name Trafikverket, took over the management of the Swedish railway infrastructure. In 1997, after an over-all transfer of functions concerning maintenance and management of railway infrastructure, a divisional management structure of the other railway areas was introduced in the "old" SJ company. In 2001, the structure constituted the basis for creation of six new railway undertakings, such as SJ $A B$ - interregional passenger transport, Green Cargo $A B$ - freight transport, Jernhusen $A B$ - railway properties, EuroMaint $A B$ - rolling stock maintenance, TrafficCare $A B$ - maintenance of stations and passenger train service, Unigrid $A B$ - IT infrastructure and logistics.

Despite the clear guidelines as to the main directions of changes in the European railways that were formed in mid-1991, the reforms of the Swedish railways, which were widely publicised in the European railway management, did not push for reform in the countries of the European Union of that time. Moreover, Continental Europe was rather distanced and awaited further, more precise recommendations of the European Commission, and did not demonstrate the will to implement railway reforms.

${ }^{3}$ Directive 91/440/EEC on the development of the Community's railways - the Official Journal of the European Communities of 1991, L 237/25.

${ }^{4}$ For more information on the railway reform in Sweden see A. Mężyk (2011), pp. 215-329. 
A country that refused to follow this conservative approach was Great Britain, where a broad public discussion on the possible privatization of the entire state railway sector (Patterson, 1997, pp. 33-39, after Mężyk, 2011, p. 242), undoubtedly inspired by liberal - conservative economic politicians, had been taking place since 1989. The preparatory work on the reform of the British Railways resulted in Railway Act ${ }^{5}$, which entered into force in April 1994. Then, in the years 1994-1996, the "old" British Railways (BR) company was completely divided6. In the first place, Railtrack company, that would serve as the manager of infrastructure, was created. Its shares were listed on the stock exchange in 1996, which meant full privatization of the manager of publicly available railway infrastructure. This was undoubtedly an unprecedented step in the history of the European railways. In addition to the railway infrastructure manager, from BR there were also distinguished 13 companies responsible for maintenance (Infrastructure Maintenance Companieis - IMC) and renewal of the infrastructure (Track Renewal Companies - TRC), as well as 6 rail freight operators (Freight Operating Companies - FOC). In the scope of passenger transport, 25 transport service areas were created, which, in the first stage of the reform, were allocated on the basis of a temporary franchise after conducting tender procedures for the same number of railway undertakings (Train Operating Companies - TOC). Furthermore, passenger rolling stock of BR was divided among 3 newly created companies (Rolling Stock Companies - ROSCO), whose aim was to rent and lease tractive rolling stock and carriages for operators of passenger transport. In later years, most of the railway and ancillary enterprises created in this way were privatized. Finally, the period of the railway infrastructure manager privatization was quite unfortunate. In October 2002, Railtrack, a listed company, had to announce forced self-liquidating ${ }^{7}$ due to high indebtedness and inability to absorb costs necessary to modernize the railway infrastructure required due to tightened safety regulations. The company was finally taken over (again) by the public administration, and its assets were transferred to a newly created non-profit company, acting as the manager of the publicly available railway infrastructure, under the name Network Rail. The company included in its structure previously separated and sold companies dealing with maintaining and renewing the IMC and TRC infrastructure.

\section{The main models of the breakdown structure of the railway sector in the European Union}

A few years after the introduction of the Swedish and British reforms, the European Union countries adopted the term "Swedish model" for solutions that involved, among others, creation of the state office managing the

\footnotetext{
${ }^{5}$ www.legislation.gov.uk/ukpga/1993/43/introduction (3.08.2017).
}

6 The processes of reform of the British Railways are discussed in more detail by: Mężyk (2011), pp. 240-276.

7 Since its establishment, Railtrack (1994 - 2002) was supposed to be a fully commercial company, maintained by fees borne by rail carriers for access to railway infrastructure. In the first years of its functioning, this way of financing the company's business activities provided high profits, which was one of the arguments for introducing its shares on London stock exchange. Since the market capitalization of Railtrack was very high in the period 1996 - 2001, it was included in the FTSE 100, the most important index of London Stock Exchange. In 2001, Railtrack paid its shareholders a high dividend in the amount of GBP 137 million, although the company was already seriously indebted for the sum of GBP 534 million. Heavy indebtedness was the result of significantly increased costs of renovation needs, when compared to the original plans, of one of the most important railways in the UK, namely West Coast Main Line, estimated at GBP 7.5 billion, as well as additional costs resulting from stricter safety regulations, after a series of spectacular railway accidents in 1997 - 2000. The British government, noticing the threats resulting from the potential bankruptcy of Raitrack, and being under the pressure of public opinion displaying negative attitude towards the private railway infrastructure manager, created Network Rail company, which at the beginning of October 2002 took over the capital of Railtrack. Then, the majority shareholders of Railtrack announced the company's liquidation, offering a purchase of its shares at PLN 2.62 per each. After court disputes with groups of shareholders, who demanded a much larger amount per share, Railtrack was finally liquidated. Cited after.: www.de.wikipedia. org/wiki/Railtrack (3.08.2017). 
railway infrastructure, and a few transport and ancillary undertakings from the remaining part of the "old railway". Another introduced term was the "British model" used for solutions that concerned assignment of the infrastructure manager from the "old" railway undertaking and its privatization through the stock market, as well as the division of the remaining integrated company in the manner described above.

Interestingly, the "Swedish model" has been successfully used to the present day by such countries as, among others, Bulgaria, Denmark, Spain, Finland, Greece, the Netherlands, Portugal, Romania and Slovakia, when introducing reforms of the railway sector (Kurzfassung..., 2011, p. 15). Whereas, the "British model" in its initial form has already ceased to exist. The railway infrastructure manager in the United Kingdom underwent renationalisation in 2002, and since then, no country in the European Union has announced any attempts to privatize the managers of the publicly available railway infrastructure. In the scope of the operation of the railway infrastructure manager, Great Brittan introduced the "Swedish model", although with the exception that the infrastructure manager, instead of being a public office, is a non-profit public company with no privatization capacity.

In the second half of the 1990s, the first experiences, advantages and disadvantages, as well as doubts related to reforms of the railway sector in Sweden and Great Britain were already known in the European Union. However, the European Commission did not focus on model solutions from these countries, all the more so since two new models of restructuring "old" railway undertakings and railway infrastructure management were created on the basis of the provisions of Directive 91/440, namely: "holding model" also known as "German model", and the quite original "French model", later called the "hybrid model".

The latter involved creation of a public unit, which formally took over the assets and liabilities of the old integrated railway undertaking, and then entrusted the management of assets (railway infrastructure) to the same railway company that previously managed the infrastructure. In 1997, the so-called Public Industrial and Commercial Unit under the name French Rail Network (RFF - Resean Ferre de France) was created. The ownership of the railway infrastructure was transferred onto RFF together with SNCF's indebtedness in the amount of over EUR 20 billion for implementation of infrastructure investments. As part of this model, RFF acted as the owner during the construction, modernization and maintenance of infrastructure operations. Whereas, the company that was managing the traffic and maintaining the railway network was SNCF. All passenger, regional and interregional, as well as freight transport services in this restructuring model were still provided by SNCF, together with many other types of supporting and ancillary activities. In general, the reform of the "old" railway undertaking in the French hybrid model was carried out in such a way so that it would not include institutional division of a railway undertaking into infrastructure and operation areas, and, at the same time, SNCF would have its debt cancelled and still maintained control over all railway activities ${ }^{8}$. Moreover, the French model of the reform of the state railway sector, the essence of which was to maintain the SNCF monopoly and which was adopted under the pressure of railway trade unions, was the subject of criticism from the European Commission and other European Union countries. It was widely assessed that France, by formally transferring the ownership of railway infrastructure to RFF and then entrusting its management to SNCF railway undertaking, which monopolized railway transport in this country, bypassed the recommendations presented in Directive $91 / 440$ in this respect. It is worth adding that a solution similar to the French proposal for the operation of the manager of the publicly available railway infrastructure was adopted in the Czech Republic (Kurzfassung..., 2011).

${ }^{8}$ The processes of the French railway reform are discussed by: Mężyk (2011), pp. 317-342. 
The holding model of the state railway sector restructuration was first created in 1999 in Germany and then reproduced in Austria, Belgium, Estonia, the Netherlands, Ireland, Lithuania, Luxembourg, Latvia, Poland, Slovenia and Italy (Kurzfassung..., 2011). It involves the initial transformation of an "old" integrated railway undertaking into a commercial company, which is in $100 \%$ state-owned, and then hiving-off the whole railway infrastructure from this company into another commercial law company that is in $100 \%$ owned by the transformed railway undertaking. Such creation of a holding of railway undertakings requires that not only railway infrastructure, but also the transport activity of the "old" railway undertaking, as well as various ancillary activities, are separated into individual companies. This type of holding, under German law known as a group, was created in Germany, where in 1999 another company called DB Netz AG was carved out from the established in 1994, state-owned company Deutsche Bahn $A G$, and operated as a manager of publicly available infrastructure. Other spin-off transport companies included DB Cargo, DB Regio, DB Fernverkehr and other ancillary and supporting companies, of which the parent company, the Deutsche Bahn AG, remained the $100 \%$ owner ${ }^{9}$. It should be added that all companies from Deutsche Bahn AG group operate in accordance with German corporate law, which includes single management of a company, free untaxed transfers of profits between companies, as well as free flow of capital injection of individual companies (lending credits to each other)

The main discussed models of changes in the breakdown structure of the state railway sector have undoubtedly contributed to comprehensive sectoral reforms in the vast majority of European Union countries. Although these reforms were slowed down in the 1990s due to the lack of many detailed regulations regarding the functioning of the railway sector, they were significantly accelerated in the 2000 s. A particular catalyst for railway reforms was the socalled first railway package from 2001, and the subsequent railway packages, as well as consolidation of European Union directives regarding the desired institutional and market governance in the EU rail sector in 2012.

\section{The breakddown-institutional governance in the EU pailway sector}

The result of changes in the railway sector, taking place in the last quarter of a century, starting from 1991 until 2016, is the business breakdown-institutional structure of the railway sector in the entire European Union, which is substantially different from the structure from the first half of the 1990s. In all European Union countries, there have been established institutional railway market regulators in accordance with the relevant directives. The manager of publicly available railway infrastructure has been selected in every European Union country - see Table 2. A uniformed licensing system of railway undertakings (operators) is applicable throughout the entire European Union, where majority of countries allowed independent rail operators, who do not come from the transformation of "old" or so-called "entrenched" railway undertakings, to enter the railway sector. It is worth noting in this context that, so far, only the English model included such a far-reaching division of an "old" railway undertaking, which concerned transformation and subsequent privatization of all its structural and tangible components, including the old name. Whereas, in most of the European Union countries, the "old" railway undertakings were subject to evolutionary and "gentle" transformations that included separation of the infrastructure, passenger and freight transport and various ancillary activities. At the same time, new enterprises were allowed to enter the railway sector, creating conditions for intra-industry competition. Therefore, in the majority of the European Union countries, there currently operate both railway undertakings continuing provision of services of their large, integrated predecessors in the field

${ }^{9}$ The reforms of the German Railways are described in details by: Mężyk (2011), pp. 277-316. 
of passenger and freight transport, as well as enterprises newly created by owners who are recruited mainly from heavy industry (e.g. from mining, metallurgy, chemical or paper industries) or the forwarding and logistics sector.

Table 2. The main managers of the publicly available railway infrastructure in the European Union countries - as of the end of 2016

\begin{tabular}{|c|c|c|c|}
\hline Country & Abbreviation & Full Name & $\begin{array}{l}\text { Length of managed } \\
\text { railway lines }(\mathrm{km})\end{array}$ \\
\hline \multicolumn{4}{|c|}{ EU - 15 Group } \\
\hline Belgium & INFRABEL & Le gestionnaire de l'infrastructure ferroviaire belge & 3,631 \\
\hline Germany & DB Netz AG & Deutsche Bahn Netz AG & 33,281 \\
\hline \multirow{2}{*}{ France } & SNCF Réseau & Société nationale des chemins de fer français - Réseau & 29,213 \\
\hline & LISEA - LGV SEA Tours-Bordeaux & Ligne à Grande Vitesse Sud Europe Atlantique & 340 (HS) \\
\hline Italy & RFI & Rete Ferroviaria Italiana & 24,278 \\
\hline Luxembourg & CFL & Société Nationale des Chemins de Fer Luxembourgeois & 275 \\
\hline The Netherlands & ProRail & ProRail B.V. & 7,028 \\
\hline Denmark & BDK Banedanmark & Banedanmark Rail Net Denmark & 2,132 \\
\hline Ireland & IR & larnród Éireann & 2,400 \\
\hline \multirow{2}{*}{ Great Britain } & NR & Network Rail & 15,779 \\
\hline & HS1 & HighSpeed1 Ltd. & 109 \\
\hline Greece & OSE & Organismós Sidirodrómon Elládos & 2,238 \\
\hline Spain & ADIF & Administrador de Infraestructuras Ferroviarias & 15,326 \\
\hline Spain/France & LFP Perthus & Linea Figueras Perpignan SA & 44 (HS) \\
\hline Portugal & Infraestruturas de Portugal & Infraestruturas de Portugal, SA & 2,553 \\
\hline Austria & ÖBB INFRA & Österreichische Bundesbahnen (ÖBB) - Infrastruktur AG & 4,846 \\
\hline Finland & Liikennevirasto & Liikennevirasto & 5944 \\
\hline Sweden & Trafikverket & Trafikverket & 12,000 \\
\hline \multicolumn{4}{|c|}{ EU - 13 Group } \\
\hline The Czech Republic & SŽDC & Správa zeleznicní dopravní cesty & 9,459 \\
\hline Estonia & EVR & Eesti Raudtee & 1,200 \\
\hline Hungary & MÁV & Magyar Államvasutak Zrt. & 7,273 \\
\hline Hungary/Austria & GYSEV/Raaberbahn & $\begin{array}{l}\text { Györ-Sopron-Ebenfurti Vasút Zrt. } \\
\text { Raab-Oedenburg-Ebenfurter Eisenbahn AG }\end{array}$ & 509 \\
\hline Lithuania & LG & Lietuvos Geležinkeliai AB & 1,868 \\
\hline Latvia & LDz infrastruktūra & Latvijas dzelzceľ̦ & 1,860 \\
\hline Poland & PLK & PKP Polskie Linie Kolejowe SA & 18,427 \\
\hline Slovenia & Slovenske železnice & Slovenske železnice- Infrastruktura, d.o.o. & 1,228 \\
\hline Slovakia & ŽSR & Železnice Slovenskej Republiky & 3,624 \\
\hline Bulgaria & NRIC - НКЖИ & Национална компания „Железопътна инфраструктура” & 4,023 \\
\hline Romania & CFR & Compania Naţională de Căi Ferate SA' & 10,600 \\
\hline Croatia & HŽ Infrastruktura & Hrvatske željeznice Infrastruktura & 2,605 \\
\hline
\end{tabular}

Source: own work based on: www.raileurope.com and www.ec.europa.eu/transport/facts-fundings/statistics/pocketbook-2016.

Table 3 presents the numbers of active railway operators (railway undertakings) in the European Union Member States according to data from the end of 2015. The data presented in Table 3, when compared with the data from Table 1, reflects the general changes in the structure of the railway sector, which took place over the years 1991-2016. If compared to the small number of integrated railway companies in the first half of the 1990s, the 
number of 750 active licensed companies in the railway sector shows metaphorically the path that the EU railway sector has taken from the branch monopoly to the market. The transition to the market in conditions of competition, did not, however, take place in all the European Union countries in the same way. The data presented in the table clearly shows that apart from countries with very large (Germany, Poland, the Czech Republic) or a large number of active licensed railway operators (Slovakia, Austria, Great Britain, Italy) and the alleged relatively strong intraindustry competition, there are countries which, according to the data, still maintain the railway branch monopoly. This particularly applies to countries with broad-gauge lines, such as Lithuania, Latvia, Ireland, Finland, Portugal, but also Luxembourg, Greece and Romania. It is also worth paying attention to over double the number of active rail freight operators in relation to passenger transport operators at the end of 2015.

Table 3. The number of active licensed railway undertakings in the European Union - as of the end of 2015

\begin{tabular}{|c|c|c|c|c|}
\hline Country & Rail freight operators & $\begin{array}{c}\text { Passenger and freight rail } \\
\text { operators }\end{array}$ & Passenger operators & $\begin{array}{l}\text { Active licensed railway } \\
\text { undertakings in total }\end{array}$ \\
\hline Germany & 140 & 30 & 107 & 277 \\
\hline Poland & 67 & 0 & 15 & 82 \\
\hline The Czech Republic & 47 & 12 & 0 & 59 \\
\hline Slovakia & 39 & 0 & 4 & 43 \\
\hline Austria & 22 & 9 & 6 & 37 \\
\hline Great Britain & 8 & 0 & 26 & 34 \\
\hline Italy & 15 & 4 & 13 & 32 \\
\hline France & 24 & 1 & 4 & 29 \\
\hline The Netherlands & 21 & 0 & 8 & 29 \\
\hline Sweden & 11 & 2 & 10 & 23 \\
\hline Estonia & 13 & 1 & 2 & 16 \\
\hline Denmark & 5 & 0 & 10 & 15 \\
\hline Belgium & 10 & 0 & 3 & 13 \\
\hline Hungary & 10 & 2 & 0 & 12 \\
\hline Bulgaria & 11 & 0 & 1 & 12 \\
\hline Spain & 10 & 0 & 1 & 11 \\
\hline Croatia & 5 & 0 & 1 & 6 \\
\hline Latvia & 2 & 1 & 1 & 4 \\
\hline Slovenia & 3 & 0 & 1 & 4 \\
\hline Romania & 1 & 1 & 1 & 3 \\
\hline Greece & 0 & 1 & 1 & 2 \\
\hline Luxembourg & 1 & 0 & 1 & 2 \\
\hline Portugal & 0 & 1 & 1 & 2 \\
\hline Finland & 0 & 1 & 0 & 1 \\
\hline Ireland & 0 & 1 & 0 & 1 \\
\hline Lithuania & 0 & 1 & 0 & 1 \\
\hline Total & 465 & 68 & 217 & 750 \\
\hline
\end{tabular}

Source: Fifth Annual Market Monitoring Report (2017), p. 62.

Freight and passenger transport are two different railway markets. In the former, it is easier to break up a branch monopoly and introduce true competition to the sector by the emergence of new entities. Hence, thanks to the liberalized rules of entry into the railway sector, many new players appeared in it. On the other hand, it is a more 
complex process to introduce conditions of true internal competition in the rail passenger transport. Therefore, there are significantly fewer European countries with higher number of passenger transport operators. At the end of 2015, the total number of real rail passenger transport undertakings operating in the entire EU market reached the level of $285(217+68$ ), of which 137 (over $48 \%$ ) operated only in Germany, which is an unprecedented case. However, 26 such carriers operated in Great Britain, 17 in Italy, 15 in Poland and in Austria respectively, 12 in Sweden and the Czech Republic respectively, and 8 in the Netherlands. The greater number of passenger rail carriers in individual Member States can be considered a positive effect of the liberalization of the railway sector. As a result, real competition mechanisms are introduced, at least partially, on the rail passenger transport market.

\section{References}

Directive 91/440/EEC on the development of the Community's railways - the Official Journal of the European Communities of 1991, L 237/25.

Fifth Annual Market Monitoring Report (2017). Retrieved from: www.irg-rail.eu-documents/2017/.

Kurzfassung der Studie Liberalisierungsindex (2011). Bahn. Retrieved from: www.bahn.de.

Mężyk, A. (2011). Uwarunkowania i efekty reform kolei. Monography No. 159. Radom Wydawnictwo Politechniki Radomskiej.

Patterson, M. (1997). Rail privatisation in Britain. The passenger's view. Rail International, 7/8, 33-39.

www.de.wikipedia.org/wiki/Railtrack.

www.ec.europa.eu/transport/facts-fundings/statistics/pocketbook-2016.

www.legislation.gov.uk/ukpga/1993/43/introduction.

www.raileurope.com.

Cite this article aS: Engelhardt, J. (2018). Changes to the business breakdown structure of the railway sector in the European Union in the period 1991-2016. European Journal of Service Management, 3 (27/2), 157-166. DOI: 10.18276/ejsm.2018.27/2-19. 